\title{
Rumen microbial diversity under influence of a polyclonal antibody preparation against lactate-producing and proteolytic bacteria in cows fed different energy sources $^{1}$
}

\author{
Diversidade microbiana ruminal sob efeito de um preparado de anticorpos policlonais \\ contra bactérias proteolíticas e produtoras de lactato em vacas alimentadas com três \\ diferentes fontes energéticas
}

\author{
OTERO, Walter Guimarães ${ }^{2}$; MARINO, Carolina Tobias ${ }^{3 *}$; BARRETO, Cristine \\ Chaves $^{4}$; PELLIZARI, Vivian Helena ${ }^{4}$; MILLEN, Danilo Domingues ${ }^{5}$; PACHECO, \\ Rodrigo Dias Lauritano ${ }^{3}$; FERREIRA, Fernanda Altieri ${ }^{2}$; DICOSTANZO, Alfredo ${ }^{6}$; \\ ARRIGONI, Mário de Beni ${ }^{3}$; RODRIGUES, Paulo Henrique Mazza ${ }^{2}$
}

\footnotetext{
${ }^{1}$ Apoio financeiro e bolsas concedidas pela Fundação de Amparo à Pesquisa do Estado de São Paulo (FAPESP, Brazil) and Conselho Nacional de Desenvolvimento Científico e Tecnológico (CNPq, Brazil).

${ }^{2}$ Universidade de São Paulo, Faculdade de Medicina Veterinária e Zootecnia, Departamento de Nutrição e Produção Animal, Pirassununga, São Paulo, Brasil.

${ }^{3}$ Universidade Estadual Paulista, Faculdade de Medicina Veterinária e Zootecnia, Departamento de Melhoramento e Nutrição Animal, Botucatu, São Paulo, Brasil.

${ }^{4}$ Universidade de São Paulo, Instituto de Biociências, São Paulo, Brasil.

${ }^{5}$ Universidade Estadual Paulista, Faculdade de Zootecnia, Dracena, São Paulo, Brasil.

${ }^{6}$ University of Minnesota, Department of Animal Science, St.Paul, United States of America.

*Endereço para correspondência: caroltobias@hotmail.com
}

\section{SUMMARY}

Nine ruminally cannulated cows fed different energy sources were used to evaluate an avianderived polyclonal antibody preparation against specific ruminal bacteria and monensin on microbial community diversity. The experimental design was three Latin squares $3 \times 3$ distinguished by the main energy source in the diet [dry-ground corn grain, high moisture corn silage or citrus pulp]. Inside each Latin square, animals received one of the feed additives per period [control, monensin or polyclonal antibody preparation]. Each period lasted 21 days where 20 were used for treatments adaptation and the last one for sampling collection. Microbial diversity was evaluated by protozoa counts and denaturing gradient gel electrophoresis. Polyclonal antibodies plus citrus pulp $(\mathrm{CiPu})$ addition in the diet resulted in an increase of relative counting of Isotricha protozoa that indicates a possible effect on this ruminal ciliate population. In general lines, in the present experiment, it was not possible to assign that there was a pattern in the structures of amplification of Bacteria and Archaea communities of the ruminal content. Oral passive immunization is a technology that arises as an effective alternative for feed additive production. Further research is still necessary to better understand its mechanisms of action.

Keywords: denaturing gradient gel by electrophoresis, feed additive, ionophores, passive immunity, protozoa

\section{RESUMO}

Nove fêmeas bovinas canuladas no rúmen alimentadas com diferentes fontes energéticas foram utilizadas para avaliar um preparado de anticorpos policlonais aviário contra bactérias ruminais específicas e monensina na diversidade da comunidade microbiana. $\mathrm{O}$ design experimental foi três quadrados latinos $3 \times 3$ distintos pela principal fonte energética na dieta [milho seco e moído, silagem de grão úmido de milho ou polpa cítrica]. Dentro de cada quadrado latino, os animais receberam um dos aditivos alimentares [controle, monensina ou preparado de anticorpos 
policlonais]. Cada período teve duração de 21 dias onde 20 dias foram utilizados para adaptação aos tratamentos e o último dia para colheita das amostras. A diversidade microbiana foi avaliada pela contagem de protozoários e pela técnica da eletroforese em gel com gradiente desnaturante. Anticorpos policlonais adicionado a polpa cítrica na dieta resultou em um aumento na contagem relativa de Isotricha o que pode indicar um efeito sobre esta população de ciliado ruminal. Em linhas gerais, no presente estudo, não foi possível determinar um padrão nas estruturas de amplificação das comunidades Bacteria e Archaea do conteúdo ruminal. A imunização passiva oral é uma tecnologia que surge como alternativa eficiente para a produção de aditivos alimentares. Novas pesquisas são ainda necessárias para melhor compreender seu mecanismo de ação.

Palavra-chave: aditivo alimentar, eletroforese em gel com gradiente desnaturante, imunidade passiva, ionóforos, protozoário

\section{INTRODUCTION}

Since the end of XVIII century, studies have shown that microorganisms present in the rumen ferment cellulose and obtain as final products short chain fatty acids, methane and carbon dioxide (BERGMAN, 1990). Since then, the scientific community has been investigating the metabolic processes that occur in ruminal environment in order to manipulate rumen fermentation to improve feed efficiency and productivity.

Recently, the immunity concept was cited as a potential tool in rumen fermentation manipulation (HARDY, 2002; BERGHMAN \& WAGHELA, 2004).

Polyclonal antibody preparation against Streptococcus bovis and Fusobacterium necrophorum in steer's high-grain diets was effective in reducing ruminal counts of target bacteria (DILORENZO et al. 2006).

Feedlot steers fed high-grain diets and orally dosed with a polyclonal antibody preparation (PAP) against S. bovis, $F$. necrophorum and several strains of proteolytic bacteria had similar performance to those fed monensin in terms of average daily gain, dry matter intake, cost of gain and feed conversion. When analyzed as percentage of body weight, steers fed PAP had greater DMI than those receiving monensin (MILLEN, 2008).

Marino et al. (2011) observed that the effects of monensin and polyclonal antibody preparation against $S$. bovis, $F$. necrophorum and several strains of proteolytic bacteria on rumen $\mathrm{pH}$ and in vivo digestibility were independent of the main energy source of the diet.

This study was designed to evaluate the feed additives monesin and polyclonal antibody preparation against $S$. bovis, $F$. necrophorum and several strains (Clostridium aminophilum, Peptostreptococcus anacrobius and Clostridium sticklandii) of proteolytic bacteria on ruminal microbial diversity of cannulated cows fed three different energy sources.

\section{MATERIAL AND METHODS}

All animal were cared for and personnel were trained, according to the guidelines established by São Paulo State University (Brazil) Ethical Committee for Animal Research (CEEA).

The procedures to generate the polyclonal antibody preparation (PAP) used in the present study were similar to those described by DiLorenzo et al. (2006, 2008) and Marino et al. (2011). The difference is that in this study a multivalent PAP (PAP-MV; RMT Optimize, CAMAS Inc., Le Center, $\mathrm{MN}$ ) was tested. Immunogens were extracted from model bacteria grown under proprietary conditions to express the surface antigens that the organism 
uses to attach to cells. Antigens were then purified from the culture and isolated "adhering" immunogens were made for injection into egg-laying hens with no adjuvant. The model organisms for this study were Streptococcus bovis (ATCC 9809) which is a main lactic acidproducing bacterium; Fusobacterium necrophorum (ATCC 27852) which is involved in the development of liver abscesses in acidotic animals; Clostridium stricklandii (ATCC 12662), Clostridium aminophilum (ATCC 49906), Peptostreptococcus anaerobius (ATCC 49031) which are hyperammonia-producing bacteria and Escherichia coli O157:H7 (ATCC 43895) which is a human pathogen that develops in ruminants under acidosis.

More than 600 hens were immunized per each immunogen. Eggs collected were analyzed weekly by specific ELISA test plates to monitor antibody binding. For the study preparations, approximately 200 immunized hens were randomly selected from the total group of hens used for egg collection. Eggs were collected for 3 days, and the product was made from eggs pooled from this collection. The PAP-MV product was made using a mixture of egg protein, molasses, soy oil, and phosphate buffered saline at $\mathrm{pH}$ 7.4. Titers by ELISA averaged between 1:50,000 and 1:1,000,000. The preparation contained immunoglobulin $\mathrm{Y}$, immunoglobulin $\mathrm{M}$, and immunoglobulin A. Concentrations of $1.4 \mathrm{mg}$ of antibody (predominantly immunoglobulin $\mathrm{Y}$ ) per $\mathrm{mL}$ of egg were observed. This included approximately 10 to $20 \%$ of the preparation that was not active. Because antibodies against many bacteria are found in most eggs, commercially available egg products or eggs were tested for antibodies to specific microbes using the same protocols used to produce egg protein. The ELISA titers did not detect binding to the specific attachment factors in these commercial eggs.

In the product RMT Optimize (CAMAS Inc., Le Center, MN) approximately $26 \%$ of antibodies acted against Streptococcus bovis, $12 \%$ against Fusobacterium necrophorum and 48\% against proteolytic bacteria Clostridium aminophilum, Peptostreptococcus anacrobius and Clostridium sticklandii. The rest of the antibodies (14\%) acted against $E$. coli $\mathrm{O} 157: \mathrm{H} 7$.

The trial was conducted at the College of Veterinary Medicine and Animal Science, University of São Paulo (USP), Brazil. Nine Holstein nonpregnant and nonlactating cows (initial weight $690 \pm$ $76 \mathrm{~kg}$ of BW; final weight $712 \pm 79 \mathrm{~kg}$ of BW) fitted with ruminal cannulas were randomly assigned to three Latin squares $3 \times 3$ where each one was based on dry-ground corn grain (CG) (yellow dent type, Agroceres 1051, Rio Claro, Brazil) or high moisture corn silage (HMCS) or citrus pulp (CiPu). Inside each Latin Square, each animal received one feed additive treatment: none $(\mathrm{CON})$, monensin $(\mathrm{MON})$ or PAP-MV in three periods of $21 \mathrm{~d}$ each. Cows were housed in a tie-stall barn equipped with individual feed bunks, rubbermatted floors and automatic water fountains shared by 2 animals. There were fans on the ceiling to relieve the high temperatures during the day. Body weight was measured at the beginning of period 1 (d 1) and at the end of each of the three periods (d 21) at the same time each day.

Diets were fed as total mixed rations with a ratio of concentrate to forage of 70:30 (DM basis). The forage source was fresh sugarcane chopped with theoretical average particle size of $1.18 \mathrm{~cm}$, measurement taken by the Penn State Particle Size Separator (KONONOFF et al., 2003). Diets were offered twice daily at 0800 and $1600 \mathrm{~h}$ throughout the 
experiment for ad libitum consumption (minimum of $10 \%$ feed refusal).

The feed additives were delivered directly through the ruminal cannula, at the moment of meals delivery; Monensin at $300 \mathrm{mg}$ of active principle $/ \mathrm{d}(3.0 \mathrm{~g} / \mathrm{d}$ of commercial product Rumensin, Elanco Animal Health, Indianapolis, IN) was administered in absorbent tissue paper $(\mathrm{MON})$ and PAP-MV at $10 \mathrm{~mL} / \mathrm{d}$ using a $10 \mathrm{~mL}$ syringe. The total daily dose was divided in two; before the morning and before the afternoon meal.

The composition and analyzed nutrient content of the experimental diets are presented in Table 1. Feed samples were dried at $55^{\circ} \mathrm{C}$ for $72 \mathrm{~h}$ and ground to pass a 1-mm screen in order to determine DM, $\mathrm{OM}, \mathrm{CP}$ by total $\mathrm{N}$ determination using the micro-Kjeldahl technique, ether extract (EE) determined gravimetrically after extraction using petroleum ether in a Soxhlet extractor, starch, calcium and phosphorus according to Silva and Queiroz (2002). Moreover, NDF (with heat-stable $\alpha$-amylase), ADF and pectin determination was according to Van Soest et al. (1991). The value of nonfiber carbohydrates (NFC) was estimated by the formula: NFC $(\% \mathrm{DM})=100-(\mathrm{CP}+$ $\mathrm{NDF}+\mathrm{EE}+\mathrm{Ash})$ according to Hall (2001).

Table 1. Composition and analyzed nutrient content of experimental diets

\begin{tabular}{lccc}
\hline \multirow{2}{*}{ Item } & \multicolumn{3}{c}{ Experimental diets } \\
\cline { 2 - 4 } & CG & HMCS & CiPu \\
\hline Ingredient (\% of DM) & 30.4 & 30.2 & 30.4 \\
\hline Sugarcane fresh and chopped & 64.2 & 15.7 & 11.2 \\
Dry-ground corn grain (CG) & - & 48.1 & - \\
High moisture corn silage (HMCS) & - & - & 50.0 \\
Citrus pulp (CiPu) & 3.10 & 3.73 & 6.73 \\
Soybean meal & 0.74 & 0.65 & 0.65 \\
Urea & 0.74 & 0.75 & 0.56 \\
Vitamin and mineral premix & 0.83 & 0.84 & - \\
Limestone & - & - & 0.47 \\
Dicalcium phosphate & & & \\
\hline Nutrient content & 59.0 & 53.5 & 61.1 \\
\hline Dry matter (\%) & 2.77 & 2.91 & 5.39 \\
Ash (\% of DM) & 11.7 & 10.8 & 10.8 \\
Crude protein (\% of DM) & 2.84 & 3.00 & 2.09 \\
Ether extract (\% of DM) & 24.9 & 23.2 & 31.4 \\
Neutral detergent fiber (\% of DM) & 16.3 & 14.3 & 21.3 \\
Acid detergent fiber (\% of DM) & 57.6 & 60.1 & 50.3 \\
Non-fiber carbohydrates (\% of DM) & 49.8 & 46.7 & 12.2 \\
Starch (\% of DM) & 0.33 & 0.34 & 11.2 \\
Pectin (\% of DM) & 78.0 & 79.0 & 73.0 \\
Total digestible nutrients (\% of DM) ${ }^{2}$ & 0.49 & 0.57 & 1.41 \\
Calcium (\% of DM) & 0.30 & 0.26 & 0.25 \\
Phosphorus (\% of DM) & \multicolumn{2}{c}{ D) }
\end{tabular}

${ }^{T}$ Composition of vitamin and mineral premix per kilogram of product: $230 \mathrm{~g}$ of Ca, $90 \mathrm{~g}$ of P, $15 \mathrm{~g}$ of S, $20 \mathrm{~g}$ of Mg, $48 \mathrm{~g}$ of $\mathrm{Na}, 100 \mathrm{mg}$ of Co, $700 \mathrm{mg}$ of Cu, $2.000 \mathrm{mg}$ of Fe, $80 \mathrm{mg}$ of I, $1.250 \mathrm{mg}$ of Mn, $20 \mathrm{mg}$ of Se, $2.700 \mathrm{mg}$ of $\mathrm{Zn}$ and $900 \mathrm{mg}$ of F (maximum), $200.000 \mathrm{UI}$ of vitamin A, $60.000 \mathrm{UI}$ of vitamin D3 and 60 UI of vitamin E.

${ }^{2}$ Value estimated by the Cornell Net Carbohydrate and Protein System software, version 5.0.40. 
Although it was used nonlactating cows as an experimental model, the diets were formulated to test the additives in feedlot diets with energy sources commonly used in practice. Considering a steer of $400 \mathrm{~kg}$ and a dry matter intake of $2.5 \%$ of body weight, test diets were formulated to attend the ME maintenance plus a weight gain of $1.24,1.53$ and $1.10 \mathrm{~kg} / \mathrm{d}$ for $\mathrm{CG}$, HMCS and $\mathrm{CiPu}$ diets, respectively. This corresponded to a dry matter intake of 1.63, 1.67 and 1.51 times the maintenance for $\mathrm{CG}$, HMCS and $\mathrm{CiPu}$ diets, respectively. Diets were formulated using the Cornell Net Carbohydrate and Protein System model version 5.0.40 (FOX et al,. 2004).

Rumen content for protozoa counts was collected at $4 \mathrm{~h}$ after morning meal at the last day of each period (day 21) by scanning the ruminal floor and fixed in $50 \%$ formalin (1:1) for microscopic counts (Olympus model $\mathrm{CH} 2$ ) according to Dehority (1993). Rumen fluid $(1 \mathrm{~mL})$ was mixed with $9 \mathrm{~mL}$ of methyl green:formaldehyde $\quad(38 \% \quad \mathrm{wt} / \mathrm{wt})$ solution. Entodiniomorphs (Entodinium, Diplodinium and Epidinium) and Isotrichids (Isotricha and Dasytricha) were identified and counted using a Neubauer Improved Bright-Line counting chamber (Hauser Scientific Partnership, Horsham, PA).

Bacterial and Archaeal diversity was evaluated by Denaturing Gradient Gel Electrophoresis (DGGE). This technique uses the nucleotide sequences of the 16SrRNA gene which is a phylogenetic marker for prokaryotic species (MUYER, 1999). For DGGE analysis of bacterial and archaeal diversity, $50 \mathrm{~mL}$ of rumen content was collected, $4 \mathrm{~h}$ after morning meal, in different portions of the rumen (anterior dorsal, medium ventral and posterior dorsal) at the last day of each period (d 21). Immediately after the collection, samples were packed in airtight glass bottles labeled and storage in a freezer at $-20^{\circ} \mathrm{C}$ for further analysis of DNA. DNA extraction was followed according to Griffiths et al. (2000) technique. The quality of extraction, purity and quantity of DNA in the final solution was evaluated by the reason between the absorbance A260 and A280 in a spectrophotometer Nanodrop ND100. The primers (Integrated DNA Technologies - IDT ${ }^{\circledR}$, USA) used for PCR of Bacteria community were: 968GCF (5' CGC CCG GGG CGC GCC CCG GGC GGG GCG GGG GCA CGG GGG GAA CGC GAA GAA CCT TAC 3') and 1401R (CGG TGT GTA CAA GGC CCG GGA ACG) (HEUER et al. 1997, NUBEL et al. 1996). For the PCR of Archaea community were used primers 1100GCF (5' CGC CCG GGG CGC GCC CCG GGC GGG GCG GGG GCA CGG GGG GAA CCG TCG ACA GTC AGG YAA CGA GCG AG 3') and 1400R (CGG CGA ATT CGT GCA AGG AGC AGG GAC) (HEUER et al. 1997, KUDO et al., 1997). PCR reactions for Bacteria and Archaea contained: 1X Platinum Taq DNA polymerase buffer (Invitrogen), $1.5 \mathrm{mM}$ of $\mathrm{MgCl}_{2}, 0.2 \mu \mathrm{M}$ of each primer, $0.2 \mathrm{mM}$ of dNTP mix containing all four dNTPs, and $2.0 \mathrm{U}$ of Platinum Taq DNA polymerase in a final volume of $50 \mu \mathrm{L}$.

The conditions for Bacteria amplifications were 1 denaturing start cycle of $3 \mathrm{~min}$ at $97^{\circ} \mathrm{C}$, followed by 30 cycles of $1 \mathrm{~min}$ at $94^{\circ} \mathrm{C} ; 1 \mathrm{~min}$ at $55^{\circ} \mathrm{C}$ and $1 \mathrm{~min}$ at $72^{\circ} \mathrm{C}$, with a final extension cycle of $3 \mathrm{~min}$ at $72^{\circ} \mathrm{C}$. For Archaea, the conditions for amplification were 1 denaturing start cycle of $5 \mathrm{~min}$ at $95^{\circ} \mathrm{C}$, followed by 30 cycles of $30 \mathrm{~s}$ at $94^{\circ} \mathrm{C} ; 30 \mathrm{~s}$ at $55^{\circ} \mathrm{C}$ and 1 min and $30 \mathrm{~s}$ at $72^{\circ} \mathrm{C}$, with a final extension cycle of $7 \mathrm{~min}$ at $72^{\circ} \mathrm{C}$.

The DGGE was performed in the Dcode "Universal Mutation Detection System" (Bio-Rad, Hercules, CA, USA) using an 
acrylamide/bis-acrylamide gel in a concentration of $8 \%(\mathrm{w} / \mathrm{v})$ for the Bacteria community and $6 \%(\mathrm{w} / \mathrm{v})$ for the Archaea community. The urea/formamide denaturing gradients ranged from 45 to $60 \%$ which separates amplicons by their nucleotide composition (MUYER, 1999). The procedure occurred in a $1 \mathrm{X}$ TAE solution at $60^{\circ} \mathrm{C}$ in a constant voltage of $60 \mathrm{~V}$ for $16 \mathrm{~h}$. Gel bands (amplicons) were visualized by silver staining. The gels were photographed (Canon Powershot A580) and images analyzed using the software Bionumerics (Biosystematica, Devon, UK). Data from the images from DGGE were used to determinate the band profile, which includes number of bands and migration of each band; for both Bacteria and Archaea communities.

Results were analyzed by Statistical Analysis System software (SAS Inst., Inc., Cary, NC, 2008), after verifying residue normality by Shapiro-Wilk test (PROC UNIVARIATE). Results of Bacteria and Archaea DNA and protozoa counts were analyzed by MIXED procedure of SAS. The model included the effects of feed additive, energy source and the interaction between feed additive and energy source as fixed factors. The effects of period, interaction between energy source and period, as well as, animal nested within energy source were considered random factors. Effects were considered significant at $P \leq 0.05$. All means presented are least-square means and effects were separated by PDIFF option of SAS.

\section{RESULTS AND DISCUSSION}

Data regarding relative $(\%)$ protozoa counts of Entodinium and Isotricha are presented on Figure 1 and 2. In general, despite of treatments, the most abundant gender observed was Entodinium. Similar results were observed by Martinele et al. (2008) and Carvalho et al. (2011). No effect for total $\left(\mathrm{x} 10^{3} / \mathrm{mL}\right)$ and relative $(\%)$ protozoa counts of Dasytricha, Epidinium and Diplodinium were observed. Relative count of Entodinium was influenced by the type of energy source $(P=0.0467)$. Animals treated with $\mathrm{CG}$ and HMCS did not differ but showed greater values of these protozoa when compared to animals receiving $\mathrm{CiPu}$ (Figure 1). Higher counting of Entodinium are expected in animals fed high proportion of grains due to its tolerance in acid environment and accelerate growth rate (6-15h) when compared to others protozoa (FRANZOLIN \& DEHORITY, 1998).

It was observed feed additive effect for Isotricha $(P=0.0404)$. The group treated with PAP-MV showed great values for relative count compared to $\mathrm{CON}$. The MON group did not differ from the others two. Also, it was observed an energy source effect for Isotricha $(P=0.0008)$, where the animals fed $\mathrm{CiPu}$ showed greater relative count than animals fed HMCG and CG but, these two did not differ between them (Figure 2).

Given the PAP effect in rise of Isotricha, this may be due to the action of this product in control population of bacteria responsible for a $\mathrm{pH}$ decrease (e.g., S. bovis). In fact, low $\mathrm{pH}$ was commonly associated to ruminal defaunation (DEHORITY, 2005). Besides, the utilization of PAP in cows submitted to high-grain diets can be associated to proliferation of other species of bacteria, a great substrate to protozoa. Bastos (2008) who tested different doses of a PAP against $S$. bovis, Fusobacterium necrophorum and proteolytic bacteria did not find any difference between PAP and control, 
regarding protozoa counting. The same was observed by Blanch et al. (2009).

The increase in Isotricha relative count in $\mathrm{CiPu}$ group can be expected as Isotrichids (Isotricha and Dasytricha) are particularly involved in the utilization of non-structural polysaccharides and soluble sugars which demonstrate their pectinolytic activity (WILLIAMS \& COLEMAN, 1988).

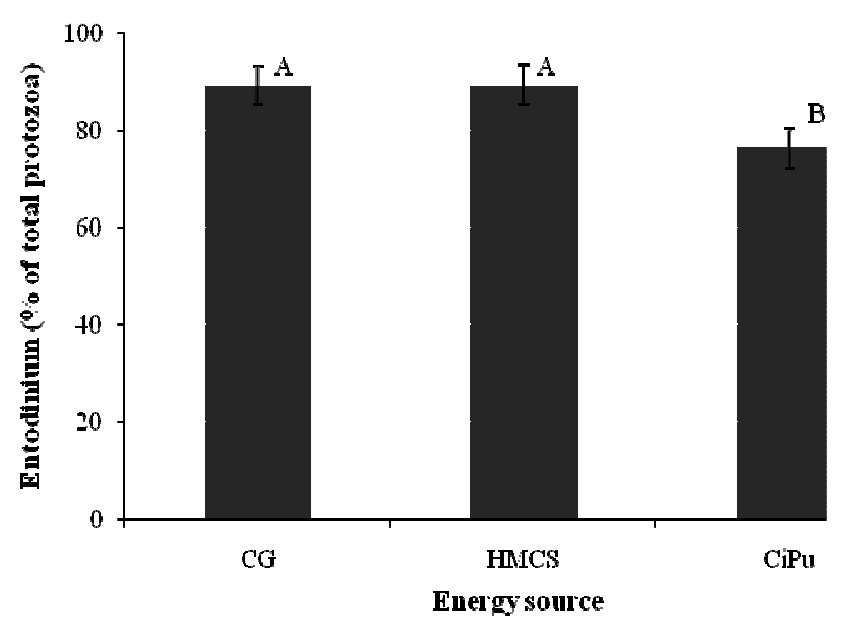

Figure 1. Relative counting of Entodinium protozoa (x $\left.10^{3} / \mathrm{mL}\right) \pm$ SEM for the main effects of energy source $(C G=$ dryground corn grain, HMCS = high moisture corn silage, $\mathrm{CiPu}=$ citrus pulp). Different letters above the bars denote a significant difference

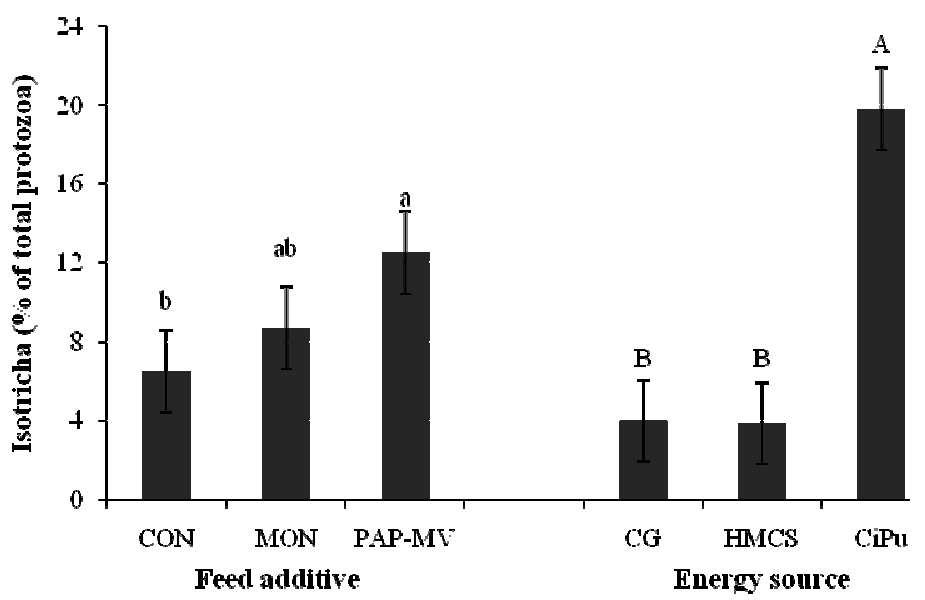

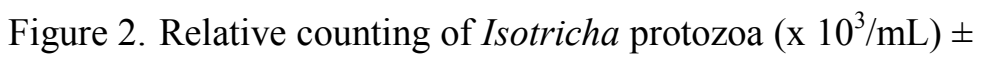
SEM for the main effects of feed additive [ Control $=$ none, $\mathrm{MON}=$ monensin $(300 \mathrm{mg} / \mathrm{dia}, \mathrm{PAP}-\mathrm{MV}=$ multivalent polyclonal antibody preparations (10 $\mathrm{mL} / \mathrm{d})]$ and energy source $(\mathrm{CG}=$ dry-ground corn grain, $\mathrm{HMCS}=$ high moisture corn silage, $\mathrm{CiPu}=$ citrus pulp). Different letters above the bars denote a significant difference 
No effect of interaction between feed additive and energy source $(P=0.3934)$, feed additive $(P=0.8411)$ or energy source $(P=0.2580)$ was observed for the number of bands observed in the DGGE for the bacterial community, indicating that bacteria community richness was not distinct in any treatment. However, an interaction between feed additive and energy source $(P=0.0423)$ was observed for the number of bands that were identified in the DGGE for Archaea community (data not shown). In animals fed HMCS, the number of bands observed in DGGE for the archaeal community was greater in CON group (5.67) compared to MON (2.33) and PAP-MV (2.67). The majority of the Archaea found in rumen belong to the group of methanogens, these microorganisms are important to remove the excess of $\mathrm{H}+$ derived from fermentation processes avoiding its negative feedback (JANSSEN and KIRS, 2008). An interaction between feed additive and energy source $(P=0.0435)$ was also observed for the total sum of bands amplified by DGGE for bacterial and archaeal community (data not shown). In animals fed HMCS, total sum was greater in CON group (16.33) compared with MON (10.00) and PAP-MV (11.67) groups.

The clustering analysis of the DGGE profiles of the Bacterial community, under influence of two feed additives on three different energy sources are presented on Figure 3.

In general lines, it was not possible to attribute a pattern in the structure of amplification of Bacteria or Archaea community of the rumen content from the animals treated with different feed additives. Band profiles in this project exhibited a similar pattern to those observed by Tajima et al. (2001) and Edwards et al. (2004), where the majority of the bands observed for Bacterial community were concentrated in the low gradient region of the gel, in other words, where DNA bands with lower quantity of $\mathrm{C}-\mathrm{G}$ bounds are established. The DNA of some bacteria like Streptococcus bovis, Selenomonas ruminantium, Anaerovibrio lipolytica and Prevotella $s p$ have a low threshold of amplification and probably more easily amplified than sequences of DNA from bacteria like Fibrobacter succinogenes (TAJIMA et al. 2001; EDWARDS et al. 2004).

This effect was not observed in actual experiment where the DGGE profiles had more intense concentration of bands in the lower gradient where is located the gram-positive bacteria. However, the positive identification of each bacteria can only be achieved by removing the band from the gel, sequencing, and analyzing each individual band.

The rumen microbiota is highly responsive to changes in diet, age, feed additives and animal host health (MIN et al. 2006). So, animals fed diets based on grain demonstrated great diversity on microbial population than animals fed diets based on forage. In an acidosis induction experiment, Blanch et al. (2009) observed that the cluster analysis by DGGE comparing the day ten of adaptation, acidosis day and day four after acidosis revealed that the clusters of the day ten of adaptation and day four after acidosis were closer to each other than to the day of acidosis. This could be explained by similarity of diets in these two periods. The great variation in the similarity of the profiles of DGGE in ruminal microbial population in this actual experiment when it was analyzed the effect of feed additives demonstrated a great difference in the microbial population between animals. This 
Rev. Bras. Saúde Prod. Anim., Salvador, v.13, n.2, p.491-502 abr./jun., 2012 http://www.rbspa.ufba.br ISSN 15199940

assertion is supported by Kocherginskaya, Aminov \& White (2001) and Min et al. (2006) who

(a)

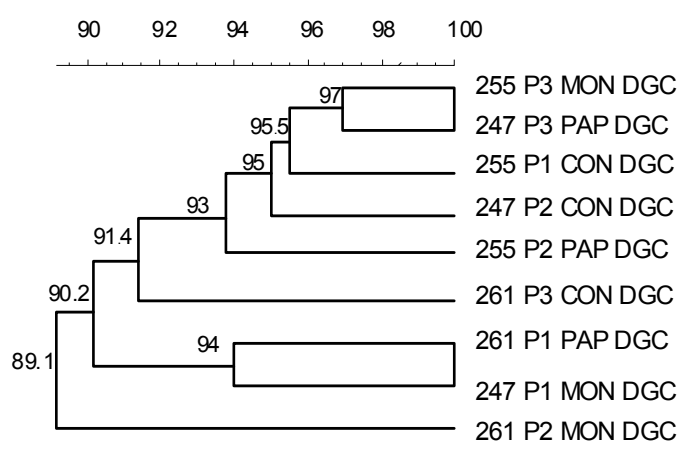

related the same variation on the similarity of the gel amplification profiles. (b)

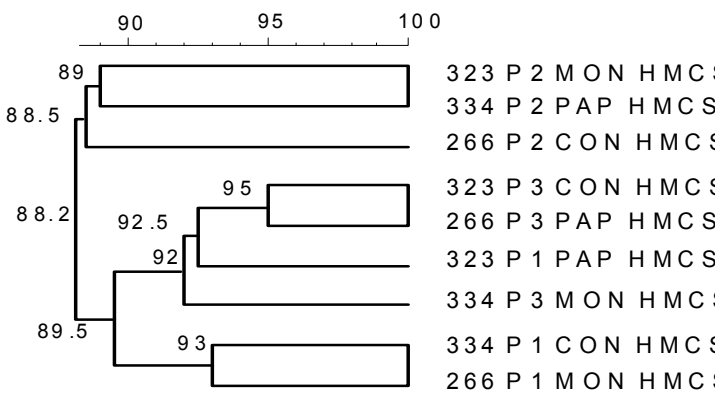

(c)

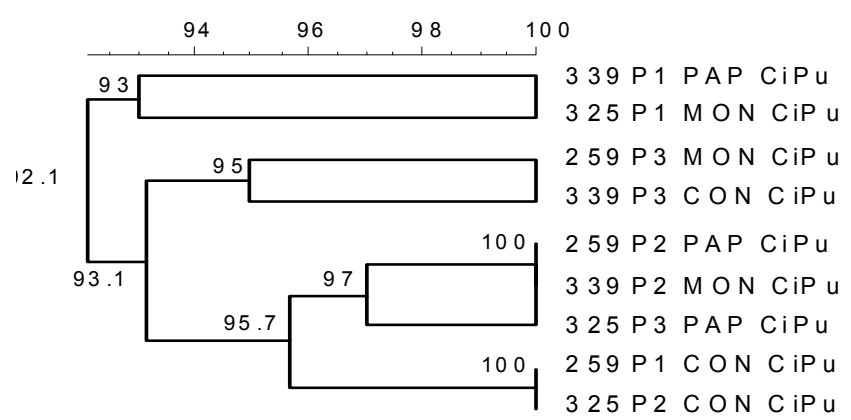

Figure 3. Clustering analysis of the Denaturing gradient gel electrophoresis (DGGE) profiles from Bacteria community from ruminal content samples of animals fed (a) dry-ground corn grain (CG), (b) high moisture corn silage (HMCS) or (c) citrus pulp $(\mathrm{CiPu})$. At the right hand side of profiles are described the animal number, period $(\mathrm{P})$, feed additive $(\mathrm{CON}=$ control, $\mathrm{MON}=$ monensin, $\mathrm{PAP}=$ polyclonal antibody preparation) and energy source. The similarity coefficients determinated by Bionumerics software, which used the group method different bands, are showed at the left hand side of each panel

The addition of citrus pulp in diet increased the total and relative counting of Isotricha resulting in a proportional decrease in the relative counting of Entodinium. Also, polyclonal antibody preparation utilization resulted in an increase of total and relative counting of Isotricha. More studies are necessary to determine other factors related to these results.

DGGE analysis from ruminal content showed that diet can alter the Archaea community. However, it could not be observed any similarity in the population profiles between animals that received the same treatment. 
Rev. Bras. Saúde Prod. Anim., Salvador, v.13, n.2, p.491-502 abr./jun., 2012 http://www.rbspa.ufba.br ISSN 15199940

\section{ACKNOWLEDGMENTS}

The authors thank CAMAS Inc. for providing the polyclonal antibodies tested in this study. Also, Gilmar E. Botteon for the good care of animals and Ari Luiz de Castro, Everson J. Lázaro, Gilson L. A. de Godoy, Simi L. D. Aflalo and Isabel G. Ramos for all the help with laboratory analysis.

\section{REFERENCES}

BASTOS, J.P.S.T. Effect of different doses of specific polyclonal antibody preparation on ruminal variables, in situ degradability and in vivo digestibility in cattle fed high concentrate diets. 2009. $111 \mathrm{p}$. Diss (MSc). São Paulo State University, Botucatu, Brazil.

BERGHMAN, L.R.; WAGHELA, S.D. Antibodies: an alternative for antibiotics? Journal of Animal Science, v.82, p.660-666, 2004.

BERGMAN, E. N. Energy contributions of volatile fatty acids from the gastrointestinal tract in various species. Physiological Reviews, v.70, n.2, p.567-590, 1990.

BLANCH, M.; CALSAMIGLIA, S.; DiLORENZO, N.; DiCOSTANZO, A.; MUETZEL, S.; WALLACE, R. J. Physiological changes in rumen fermentation during acidosis induction and its control using a multivalent polyclonal antibody preparation in heifers. Journal of Animal Science, v.87, n.5, p.17221730, 2009.
CARVALHO, L.F.P.B.; AMORIM, G.L.; MATOS, D.S.D.; BATISTA, A.M.V.; MORAES, A.C.A.D.; CABRAL, A.M.D. Protozoários do rúmen de caprinos submetidos a dieta com casca de soja. Revista Brasileira de Sáude e Produção Animal [Online], v.12, n.1, p.244-253, 2011.

DEHORITY, B.A. Laboratory manual for classification and morphology of rumen ciliate protozoa. Florida, USA: CRC Press Inc., 1993.

DEHORITY, B.A. Effect of $\mathrm{pH}$ on viability of Entodinium caudatum, Entodinium exiguum, Epidinium caudatum and Ophryoscolex purkynjei in vitro. The Journal of Eukaryotic Microbiology, v.52, n.4, p.339-342, 2005.

DiLORENZO, N.; DIEZ-GONZALEZ, F.; DiCONSTANZO, A. Effects of feeding polyclonal antibodies preparations on ruminal bacterial populations and ruminal $\mathrm{pH}$ of steers fed high-grain diets. Journal of Animal Science, v.84, n.8, p.2178-2185, 2006.

DiLORENZO, N.; DAHLEN, C.R.; DIEZ-GONZALEZ, F.; LAMB, G.C.; LARSON, J.E.; DiCOSTANZO, A. Effects of feeding polyclonal antibody preparations on rumen fermentation patterns, performance, and carcass characteristics of feedlot steers. Journal of Animal Science, v.86, n.11, p.30233032, 2008.

EDWARDS, J.E.; MCEWAN, N.R.; TRAVIS, A.J.; WALLACE, R.J. 16S rDNA library-based analysis of ruminal bacterial diversity. Antonie Van Leeuwenhoek, v.86, p.263-281, 2004. 
Rev. Bras. Saúde Prod. Anim., Salvador, v.13, n.2, p.491-502 abr./jun., 2012 http://www.rbspa.ufba.br ISSN 15199940

FOX, D.G.; TEDESCHI, L.O.; TYLUTKI, T.P.; RUSSELL, J.B.; Van AMBURGH, M.E.; CHASE, L.E.; PELL, A.N.; OVERTON, T.R. The Cornell Net Carbohydrate and Protein System model for evaluating herd nutrition and nutrient excretion. Animal Feed Science Technology, v.112, n.14, p.29-78, 2004.

FRANZOLIN, R.; DEHORITY, B.A. Effect of prolonged high concentrate feeding on ruminal protozoa concentrations. Journal of Animal Science, v.74, n.11, p.2803-2809, 1998.

GRIFFITHS, R.I.; WHITELEY, A.S.; O'DONNELL, A.G.O.; BAILEY, M.J. Rapid method for coextraction of DNA and RNA from natural environments for analysis of ribosomal DNA- and RNAbased microbial community composition. Applied Environmental Microbiology, v.66, n.12, p.5488-5491, 2000.

HALL, M.B. Recent advanced in nonndf carbohydrates for the nutrition of lactating cows. In: INTERNATIONAL SYMPOSIUM IN DAIRY CATTLE, 2001, Lavras, MG. Anais... Lavras, MG: UFLA/FAEPE, 2001. p.139-148.

HARDY, B. The issue of antibiotic use in livestock industry. What have we learned? Animal Biotechnology, v.13, n.1, p.129-147, 2002.

HEUER, H.: KRSEK, M.; BAKER, P.; SMALLA, K.; WELLINGTON, E.M.H. Analysis of Actinomycete communities by specific amplification of genes encoding 16S rRNA and gelelectrophoretic separation in denaturing gradients. Applied and Environmental Microbiology, v.63, n.8, p.3233-3241, 1997.
JANSSEN, P.H.; KIRS, M. Structure of the Archaeal community of the rumen. Applied and Environmental Microbiology, v.74, n.12, p.3619-3625, 2008.

KOCHERGINSKAYA, S.A.; AMINOV, R.I.; WHITE, B.A. Analysis of the rumen bacterial diversity under two different diet conditions using denaturing gradient gel electrophoresis, random sequencing, and statistical ecology approaches. Anaerobe, v.7, n.3, p.119-134, 2001.

KONONOFF, P.J.; HEINRICHS, A.J.; BUCKMASTER, D.R. Modification of the Penn State Forage and Total Mixed Ration Particle Separator and the effects of moisture content on its measurements. Journal of Dairy Science, v.86, n.5, p.1858-1863, 2003.

KUDO, Y.; NAKAJIMA, T.; MIYAKI, T.; OYAIZU, H. Methanogen flora of paddy soils in Japan. FEMS

Microbiology Ecology, v.22, n.1, p.3948, 1997.

MARINO, C.T.; OTERO, W.G.; RODRIGUES, P.H.M.; DICOSTANZO, A.; MILLEN, D.D.; PACHECO, R.D.L.; DILORENZO, N.; MARTINS, C.L.; ARRIGONI, M.D.B. Effects of adding polyclonal antibody preparation on ruminal fermentation patterns and digestibility of cows fed different energy sources. Journal of Animal Science, v.89, n.5, p.3228-3235, 2011.

MARTINELE, I.; SIQUEIRACASTRO, I.C.V.; D’AGOSTO, M. Protozoários ciliados no rúmen de bovinos alimentados com dietas de capim-elefante e dois níveis de concentrado. Revista Brasileira de Sáude e Produção Animal [Online], v.9, n.1, p.74-81, 2008. 
Rev. Bras. Saúde Prod. Anim., Salvador, v.13, n.2, p.491-502 abr./jun., 2012 http://www.rbspa.ufba.br ISSN 15199940

MILLEN, D.D. Performance, rumen papillae evaluation and metabolic profile of feedlot cattle supplemented with sodic monensin or polyclonal antibodies. 2008. 131p. MSc Diss. São Paulo State University, São Paulo.

MIN, B.R.; PINCHAK, W.E.; ANDERSON, R.C.; HUME, M.E. In vitro bacterial growth and in vivo ruminal microbiota populations associated with bloat in steers grazing wheat forage. Journal of Animal Science, v.84, n.10, p.2873-2882, 2006.

MUYER, G. DGGE/TGGE, a method for identifying genes from natural communities. Current Opinion in Microbiology, v.2, n.3, p.317-322, 1999.

NÜBEL, U.; ENGELEN, B.; FELSKE, A.; SNAIDR, J.; WIESHUBER, A.; AMANN, R.I.; LUDWIG, W.; BACKHAUS, H.J. Sequence heterogeneities of genes encoding $16 \mathrm{~S}$ rRNAs in Paenibacillus polymyxa detected by temperature gradient gel electrophoresis. Journal of

Bacteriology, v.178, n.19, p.5636-5643, 1996.
SAS INSTITUTE. User's guide: statistics. Version 9.2. Cary, 2008.

SILVA, D.J.; QUEIROZ, A.C. Análise de alimentos: métodos químicos e biológicos. 2ed. Viçosa: Universidade Federal de Viçosa, 2002. 165p.

TAJIMA, K.; AMINOV, R.I.; NAGAMINE, T.; MATSUI, H.; NAKAMURA, M.; BENNO, Y. Dietdependent shifts in the bacterial population of the rumen revealed with real-time PCR. Applied

Environmental Microbiology, v.67, n.6, p.2766-2774, 2001.

VAN SOEST, P.J.; ROBERTSON, J.B.; LEWIS, B.A. Symposium:

Carbohydrate methodology, metabolism, and nutritional implications in dairy cattle. Methods for dietary fiber, neutral detergent fiber, and nonstarch polysaccharides in relation to animal nutrition. Journal of Dairy Science, v.74, n.10, p.3583-3597, 1991.

WILLIAMS, A.G.; COLEMAN, G.S. The rumen protozoa. In: HOBSON, P.N. The rumen microbial ecosystem. London, UK: Elsevier Applied Science, 1988. p.77-128.

Data de recebimento: 11/04/2011

Data de aprovação: 19/03/2012 